\title{
Lesson Study for Learning Community to Support Creative Teachers in Designing Quality Learning: Lesson Study Practices on Bawean Island, Gresik Regency
}

\author{
Author \\ Nur Fauziyah (Orcid ID. 0000-0002-6146-0225), \\ Ulfatul Ma'rifah (Orcid ID. 0000-0002-7276-3141), \\ Slamet Asari (Orcid ID. 0000-0001-7924-1023), \\ Churun L. Maknun (Orcid ID. 0000-0001-7083-3401) \\ Correspondence \\ Universitas Muhammadiyah Gresik \\ nurfauziyah@umg.ac.id
}

\begin{abstract}
This study aims to describe the implementation of LSLC (Lesson Study for Learning Community), which was carried out on a remote island. The subjects in this study were 29 teachers of MTs (Madrasah Tsanawiyah) and MA (Madrasah Aliyah) Penaber on the island of Bawean Gresik. To find out the impact of LSLC on increasing teacher creativity in developing quality learning tools, LSLC product analysis was carried out in chapters and lesson designs. Quantitative data from the pre-test and post-test results are also used to compare the impact of increasing teacher understanding of the LSLC principle. Based on this study, it was found that LSLC activities increased teacher creativity in designing quality learning. Learning that focuses on efforts to solve student problems in education. Learning that emphasizes knowledge can grow students' abilities in critical thinking, creativity, collaboration and communication. During the implementation of LSLC, it also impacts increasing the positive attitude of teachers and communication and collaboration skills. The quantitative data analysis also shows that during the performance of the LSLC there is an influence on the teacher's understanding of the LSLC principles.
\end{abstract}

Keywords : lesson study, learning community, creativity, remote area

Received: 17 May 2021. Accepted: 23 June 2021

\section{Introduction}

areas. The small room is the island of Bawean, which is located 80 miles or $130 \mathrm{~km}$ north of the island of Java. Administratively, this island is included in Gresik Regency, East Java Province. Bawean Island consists of two sub-districts, namely the Sangkapura subdistrict and the Tambak sub-district. The population is around 113,839 people, with livelihoods as fishermen, farmers and most of them work as TKI (Indonesian Workers) in Malaysia and Singapore. The majority ethnicity of the Bawean population is the Bawean, Javanese, Madurese, Bugis and Mandailing ethnicities. Their daily spoken language is Bawean language which is almost similar to Madurese.

Geographical location and transportation conditions that connect Bawean
Island with Gresik Regency are the main factors for the low quality of education. Lagging in the IT field makes teachers on this island still carry out conventional or traditional learning. Teachers in Bawean Island are rarely able to attend pieces of training to improve their pedagogic and professional abilities. They cannot upgrade their knowledge because of the many obstacles to become teachers who are left behind. The government, especially the Gresik Regency Education Office, is still having trouble solving this problem.

Even though it should be under the demands of the 21 st century or the era of the industrial revolution 4.0, teachers should have implemented learning that focuses on $4 \mathrm{C}$ (Critical Thinking, Creative, Communicative and Collaborative). In addition, the material 
presented should be HOTS (High Order Thinking Skill).

Based on these problems, through this program, a solution is offered by applying a model of professional development for special educators in remote areas by implementing lesson study. The model has been previously developed through a study. The model is implemented through the lesson study stages, namely plan, do, see, and redesign. Plan activities are activities carried out in the form of workshops to develop learning tools. The do activity is to carry out learning in class. See activity is an observation activity in the learning process. Furthermore, redesign activities are activities to design learning based on the results of observations. This activity is carried out collaboratively between teachers and lecturers, called lesson study for the learning community (LLC).

Through this activity, it is expected to: Increase understanding and insight into the concepts and best practices of implementing learning community-based learning. Through this activity, it is expected to: (1) increase understanding and insight into the concepts and best practices of implementing learning community-based learning, (2) improve the ability of teachers to design learning community-based learning, (3) improve the ability of teachers to implement learningbased learning. community, (4) improve the ability of teachers to observe the learning process based on learning community, (5) improve the ability of teachers to reflect on learning community-based learning, (6) improve the ability of teachers in redesigning learning community-based learning.

This LSLC activity is carried out through a community service program carried out at MTs (Madrasah Tsanawiyah) and MA (Madrasah Aliyah) di Penaber, Tambak, Island Bawean Gresik Regency.

\section{Method}

This LSLC implementation method uses stages consisting of 4 stages according to the following figure.

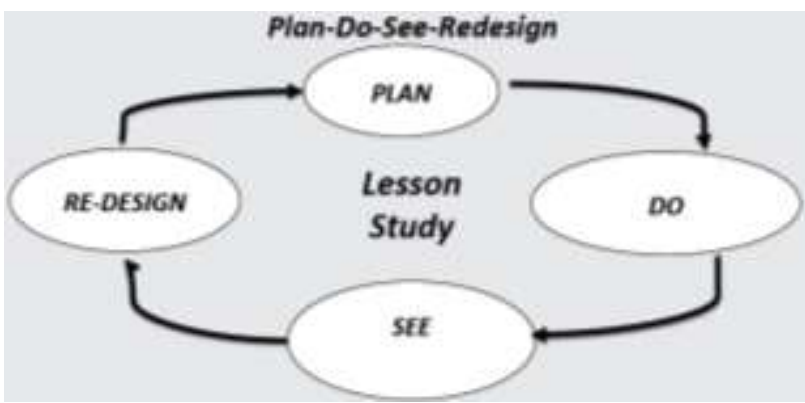

Figure 1. Cycle of LSLC The planned activity is a collaboration between teachers in preparing learning tools.

It must pay attention to the following things:

1. Review the curriculum and formulate learning objectives and student development goals.

2. Make teaching plans through collaboration with fellow teachers.

3. This activity This is done collaboratively between teachers and assistants.

The companion, in this case, is from the lecturer.

The do activity is an activity to carry out learning in class based on previously prepared learning tools. He was conducted by one of the teachers involved in learning planning activities in his community. During the implementation of learning, observations were also made (see). Attention is focused on student behaviour in the classroom (not on the teacher's teaching activities). Next is the redesign stage. This stage is intended to improve learning tools under suggestions and input from observers at the time of reflection. This stage is re-agreed on the redesign of learning devices to produce better learning tools than before. This article focuses more on discussing the results of learning design at the planning stage.

\section{Result and Discussion}

The LSLC was implemented by involving all teachers in MTs and MA Penaber on Bawean Island. Plan activities are carried out through workshops. Workshop with Lesson Study for Learning Community in Schools, Lesson Study for Learning Community in Classroom, Observation and Reflection Techniques, and Practice and Analysis of Observation Results. For this session, the resource persons started by 
presenting the material in plenary followed by group discussion. To be directed, participants are provided with learning journal sheets. The sheet guides participants to be able to write down the new knowledge gained reflectively. At the end of the session, several groups were allowed to present their work, and the resource persons gave feedback, including confirmation, concept clarification, and additional/enrichment of information.

Group work sessions are divided based on subjects, namely Mathematics, Natural Sciences, Indonesian Language, and Islam. A resource person facilitates each group. Open class activities in schools by observing the learning process carried out, followed by reflection on the results of learning activities and, in the end, preparing improvements to the learning design. These stages are carried out continuously so that the objectives of this program will be achieved.

The following are the results of the chapter and lesson design activities for each group.
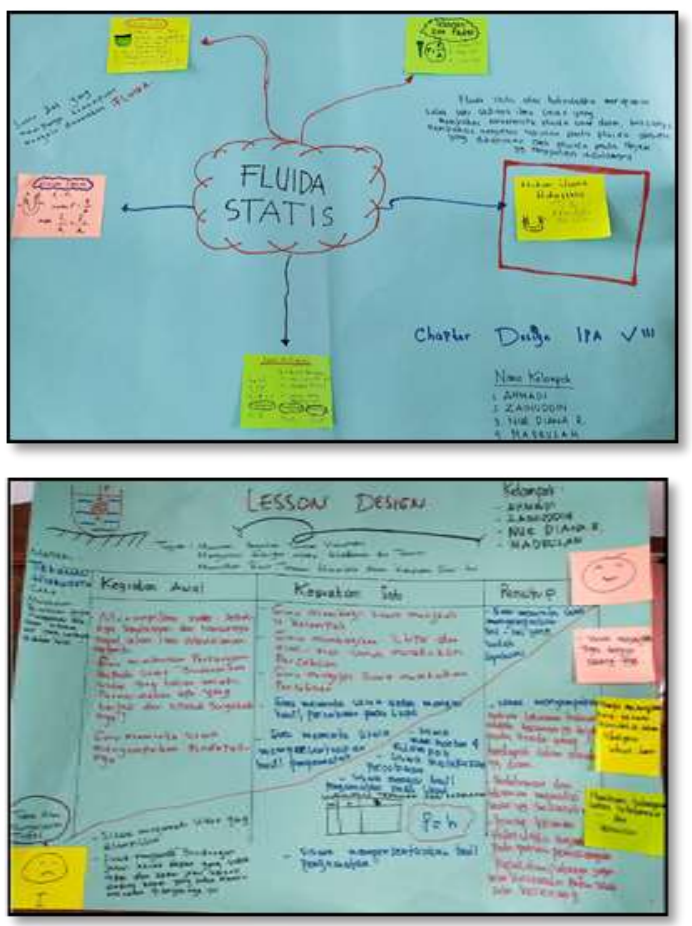

Figure 2. Chapter and Lesson design of science subjects
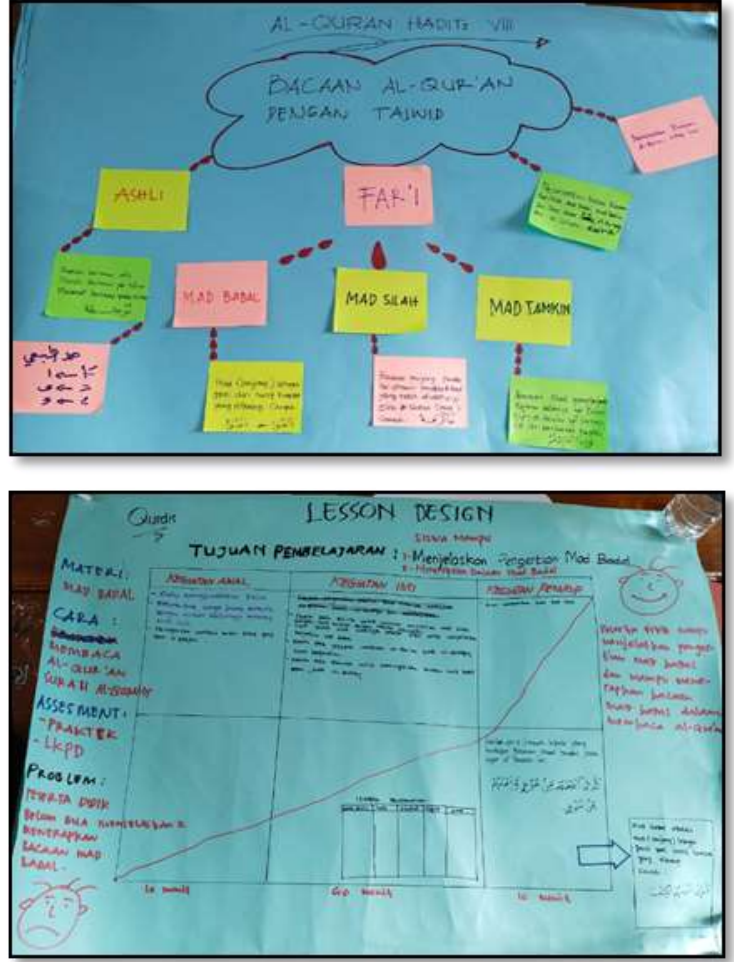

Figure 3. Chapter and Lesson design of religion subjects
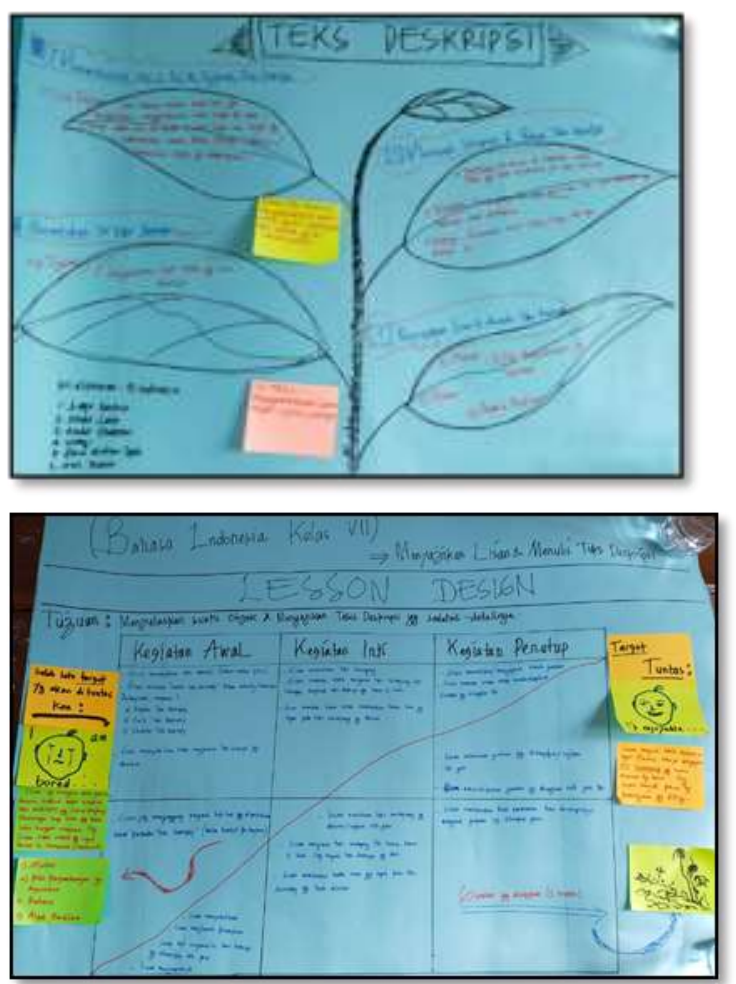

Figure 4. Chapter and Lesson design of Indonesia language subjects

In preparing the design chapter, the first major topic can be selected in one chapter. The teacher discusses breaking the topic into several sub-topics. Chapter design 
aims to map our understanding of the materials in a chapter (concrete the material that students will learn). This is an activity carried out by students to achieve the target material. The steps in preparing the design chapter are (1) determining the material to be made in the design chapter, (2) making a concept map or mind mapping of the material, and (3) determining a topic of discussion that will be made a lesson design.

Furthermore, the teacher works collaboratively in preparing lesson designs. Lesson design is slightly different from the general lesson plan but the essence is the same. RPP serves to facilitate students classically. Lesson design is made to think about how students learn from beginning to end to achieve goals. In making lesson design we position ourselves as students, not as teachers. The steps in preparing a lesson design are (1) determining a topic for a lesson design, (2) creating a table consisting of 3 columns in manila, (3) drawing a line with colored markers starting from the top right corner to the left corner. using the left hand, (4) the area above the line is the teacher's assistance for student activities, while the area below the line is the teacher's predictions about student activities, (5) determining the objectives of learning, (6) determining one student (student who has in learning), (7) identify the problems experienced by students who have difficulty in learning, (8) determine the condition of students who have learning difficulties at the end of the lesson, and (9) design learning activities starting from the initial activities, sharing tasks and jumping tasks (N. Fauziyah et al., 2021).

Sharing tasks in the form of questions with the level that is being given to students which aims to make students discuss collaboratively, provide input to each other so as to create a learning community among students. In the discussion of working on sharing tasks will create good communication between students. While the jumping task is a question that is made at a higher level with the aim of providing opportunities for students to think at higher levels and find their creativity in solving a problem. Ability in higher order thinking and creative thinking for students is an ability that must be developed in a classroom learning (Nashruddin \& Nurrachman, 2016).

Based on observations and interviews with several teachers, this collaborative activity has never been done before. Teachers have never designed learning in a way like in this LSLC program. They just felt how to compile a design chapter before compiling a lesson design. They feel that they get new experiences on how to compose lesson designs that focus on solving learning problems experienced by students in the classroom. How to develop lesson design that focuses on how students can think critically, creatively, improve communication and collaboration skills. This is in accordance with previous research that lesson study can provide opportunities for students to think as broadly as possible (Inprasitha \& Changsri, 2014)

After they finished the chapter and lesson design, each group presented the results and the other groups gave input. This section can also increase the courage of opinion and communication skills of all teachers. They are very enthusiastic in expressing their opinions to provide constructive input. No teacher looks superior and everyone expresses their opinions politely. This is in accordance with previous research which showed that LSLC can increase positive attitudes towards teachers (Jhang, 2020).

This activity will form a learning community among teachers. This will change habits or culture, that so far there has never been a discussion between teachers discussing how to learn in class. If this is done continuously, the learning community among teachers will become entrenched in the school. The final impact of this culture is of course an increase in the quality of learning which has an impact on the quality of graduates in this school (Cerbin \& Kopp, 2006).

Furthermore, during the implementation of the LSLC, the participants' pretest and posttest data were also taken with the following analysis results. To find out whether there is an effect of implementing LSLC on teachers' understanding of lesson 
study. Here are the results of the normality test.

Table 1. Normality test results

\begin{tabular}{|l|l|l|l|l|l|l|}
\hline \multirow{2}{*}{} & \multicolumn{3}{|l|}{ Kolmogorov-Smirnov } & \multicolumn{3}{l|}{ Shapiro-Wilk } \\
\cline { 2 - 7 } & $\begin{array}{l}\text { Statist } \\
\text { ic }\end{array}$ & df & Sig. & Statistic & df & Sig. \\
\hline Pre test & 160 & 22 & .148 & .912 & 22 & .051 \\
Post test & 419 & 22 & .000 & .556 & 22 & .000 \\
\hline
\end{tabular}

a. Lilliefors Significance Correction

Based on the results of the normality test of both the Kolmogorov-Smirnov and Shapiro-Wilk tests, the Sig value was obtained. $>0.05$ for the pre-test, which means that the pre-test data is normally distributed. However, the value of Sig. $<0.05$ for the post test, which means the data is not normally distributed. Therefore, for further statistical testing using non-parametric statistics. In this study, statistical tests were used to determine whether or not there was a difference in the average of two paired samples. Wilcoxon test was used because the data were not normally distributed. The hypotheses proposed in this study are:

Null hypothesis: There is no difference in the value of pre test and post test. Alternative hypothesis: There is a difference in the value of pre-test and post-test. Hipotesis ini bermakna bahwa ketika ada perbedaan antara nilai pre test dan post test menunjukkan ada pengaruh pelaksanaan LSLC terhadap nilai pemahaman peserta terhadap lesson study.

Table 2. Wilcoxon Signed Test

\begin{tabular}{|ll|l|l|l|}
\hline & $\mathrm{N}$ & Mean Rank & $\begin{array}{l}\text { Sum of } \\
\text { Ranks }\end{array}$ \\
\hline $\begin{array}{l}\text { Post } \\
\text { test }\end{array}$ - Regative \\
Pre test & $0^{\mathrm{a}}$ & .00 & .00 \\
& $\begin{array}{l}\text { Positive } \\
\text { Ranks } \\
\text { Ties }\end{array}$ & $17^{\mathrm{b}}$ & 9.00 & 153.00 \\
Total & 22 & & \\
\hline
\end{tabular}

a. Post test $<$ Pre test

b. Post test > Pre test

c. Post test $=$ Pre test
From table 2, it is obtained that the value of negative ranks is 0 . This indicates that there is no decrease from the pre-test to the post-test. The positive rank value indicates that there are 17 participants out of 22 participants who experienced an increase from the pre test value to the post test value, where the average increase was 9.00. There are 5 participants who did not experience an increase in the value of the pre test to the value of the post test

Table 3. Wilcoxon statistical test results

\begin{tabular}{|l|l|}
\hline & Post test - Pre test \\
\hline$Z$ & $-3.663^{\mathrm{a}}$ \\
Asymp. Sig. (2-tailed) & .000 \\
\hline
\end{tabular}

a. Based on negative ranks.

b. Wilcoxon Signed Ranks Test

Based on table 3 , it is known that Asym.sig (2-tailed) is worth 0.000 which is smaller than 0.05 , it can be concluded that the alternative hypothesis is accepted. This means that there is a difference between the pre-test and post-test scores. So it can be concluded that "There is an effect of lesson study for learning community workshops on participants' understanding of LSLC".

Based on the qualitative observational data and quantitative data above, it shows that LSLC activities are able to increase the creativity of teachers in remote areas in collaborating in developing quality learning tools. (Anwar et al., 2019; Asari et al., 2018; Nur Fauziyah \& Uchtiawati, 2017).

This LSLC needs to be applied to all teachers because teachers have several challenges in learning including: (1) In the industrial era 4.0 has characteristics related to the development of digital technology, internet of things, internet of people, internet of services related to changes in community culture (Society 5.0), including changes in the teacher's mindset, (2) teachers are a key factor to innovate by preparing the nation's future generation, so that teachers are not teachers but designers of HOT learning as out-of-the- 
box thinking, and (3) a shift from full-time teacher becomes classroom-collaboration: collaboration between teachers, teacherstudents, students; teacher center to student center by inviting students to think for example: project based learning, problem based learning and others. This is in accordance with previous research which showed that school-based lesson study improved more aspects of pedagogic knowledge while subject association lesson study increased pedagogic knowledge, content knowledge, and technology knowledge. (Rochintaniawati et al., 2019).

The LSLC principles that can be developed include (1) Learning improvement: The collaborative spirit of the PrincipalTeacher-Parents-Community to improve the quality of learning towards a better direction, (2) Learning from each other and listening to each other: "Teachers do not teach but teach" because learning is the right of every student, (3) the teacher is not the only source of learning and the teacher is not the "master" of the class, (4) interesting, fun, and meaningful learning, (5) developing the potential and uniqueness of students, students' multiple intelligence through $\mathrm{Ki}$ Hajar Dewantara's concept of honing, loving, and nurturing each other (among) and each student is a champion so that in fact there are no "stupid" students but there are "misguided", and (6) schools are not only to increase the number of outstanding students but more to reduce the number of problem students.

\section{Conclusion}

Based on the discussion above, it can be concluded that LSLC activities are able to increase teacher creativity in designing quality learning. Learning that focuses on efforts to solve student problems in learning. Learning tools that emphasize how learning can grow students' abilities in critical thinking, creative, collaborative and communication. During the implementation of LSLC, it also has an impact on increasing the positive attitude of teachers as well as communication and collaboration skills. The quantitative data analysis also shows that during the implementation of the LSLC there is an influence on the teacher's understanding of the LSLC principles.

\section{Suggestion}

Based on the conclusions above, LSLC should be implemented by taking into account the following points, namely: (1) carried out continuously, (2) involving all elements, namely teachers, principals, supervisors, parents, committees and education offices (3) LSLC can be done at the level of the subject teacher, school level or MGMP. This is because schools are responsible for guaranteeing the right to learn for every child without exception, improving the quality of learning, and preparing a democratic society.

Meanwhile, the principal's role is to organize to reform learning, visit and see students learn every day, and learn about Collaborative Learning with teachers. Supervisors play a role in monitoring the implementation of Learning Community in schools and assisting the implementation of Learning Community in schools. The role of parents and committee is to give consideration in determining and implementing LSLC activities and supporting the realization of LSLC implementation. Meanwhile, the role of the education office is to supervise primary and secondary education units in the implementation of the LSLC, to facilitate the improvement of the quality of education through the LSLC, and to carry out cooperation in the field of LSLC quality assurance.

\section{References}

Anwar, K., Asari, S., Fuziyah, N., Arifani, Y., \& Suryanti, S. (2019). Factors affecting services for computer assisted learning in a remote area: Analysis of structural equation modeling. International Journal of Recent Technology and Engineering, 8(3). https://doi.org/10.35940/ijrte.C5304.098 319

Asari, S., Fauziyah, N., \& Uchtiawati, S. (2018). Improving Teacher Pedagogic Competences in Remote Areas through Lesson Study Activity. International Journal of Education and Literacy 
Studies, $6(2)$. https://doi.org/10.7575/aiac.ijels.v.6n.2p. 53

Cerbin, W., \& Kopp, B. (2006). Lesson Study as a Model for Building Pedagogical Knowledge and Improving Teaching. International Journal of Teaching and Learning in Higher Education, 18(3).

Fauziyah, N., Asari, S., Ma'Rifah, U., Uchtiawati, S., \& Husniati, A. (2021). Improving Students' Creativity through Sharing and Jumping Task in Mathematics Lesson Study Activity. Journal of Physics: Conference Series, 1764(1). https://doi.org/10.1088/17426596/1764/1/012100

Fauziyah, Nur, \& Uchtiawati, S. (2017). Developing a Model of Educators' Professional Training Special for Remote Areas through the Implementation of Lesson Study. International Education Studies, 10(8). https://doi.org/10.5539/ies.v10n8p108

Inprasitha, M., \& Changsri, N. (2014). Teachers' Beliefs about Teaching Practices in the Context of Lesson Study and Open Approach. Procedia - Social and Behavioral Sciences, 116. https://doi.org/10.1016/j.sbspro.2014.01. 999

Jhang, F. H. (2020). Teachers' attitudes towards lesson study, perceived competence, and involvement in lesson study: evidence from junior high school teachers. Professional Development in Education, 46(1). https://doi.org/10.1080/19415257.2019.1 585383

Lewis, C., Perry, R., \& Murata, A. (2006). How Should Research Contribute to Instructional Improvement? The Case of Lesson Study. Educational Researcher, 35(3).

https://doi.org/10.3102/0013189X03500 3003

Nashruddin, W., \& Nurrachman, D. (2016). The Implementation of Lesson Study in English Language Learning: A Case Study. DINAMIKA ILMU, 16(2). https://doi.org/10.21093/di.v16i2.356
Puchner, L. D., \& Taylor, A. R. (2006). Lesson study, collaboration and teacher efficacy: Stories from two school-based math lesson study groups. Teaching and Teacher Education, 22(7). https://doi.org/10.1016/j.tate.2006.04.01 1

Rochintaniawati, D., Riandi, R., Kestianty, J., Kindy, N., \& Rukayadi, Y. (2019). The analysis of biology teachers' technological pedagogical content knowledge development in lesson study in West Java Indonesia. Jurnal Pendidikan IPA Indonesia, 8(2). https://doi.org/10.15294/jpii.v8i2.19303

Sato, T., Tsuda, E., Ellison, D., \& Hodge, S. R. (2020). Japanese elementary teachers' professional development experiences in physical education lesson studies. Physical Education and Sport Pedagogy, 25(2).

https://doi.org/10.1080/17408989.2019.1 692808

Seleznyov, S. (2019). Lesson study beyond Japan: evaluating impact. International Journal for Lesson and Learning Studies, 8 https://doi.org/10.1108/IJLLS-09-20180061 